\title{
Education of Craft with Fabrics in Home Economics for Elementary School Students
}

\author{
Yukiko Momota \\ Ichinomiya Junior High School \\ Takamatsu, Kagawa, Japan \\ Ikuko Ogawa \\ Faculty of Education, Kagawa University \\ Takamatsu, Kagawa, Japan
}

\begin{abstract}
The effects of the teacher types in charge of home economics class survey of elementary school education of craft with fabrics was analyzed by the questionnaire for the junior high school student immediately after enrollment. There were no significant differences of the impressions and the experiences of the craft classes. However, there were significant differences in the knowledge and some skills of the craft. Higher results were obtained by the students studied with classroom teachers than a home economics major teacher. We made some suggestions on craft education in elementary school teacher course at university were made.
\end{abstract}

Keywords: craft education; fabric; home economics; elementary school students

\section{Introduction}

Craft with fabric in home economics is a compulsory content for all students from fifth grade of elementary school to junior high school in Japan. It is regarded as one of the important educational activities to have interests and attitudes to devising for the students' lives and their families. If there are different learning environments in studying craft with fabrics in elementary schools, the subsequent effects may be greatly affected because the students learn most fundamental knowledge and techniques in elementary schools. We studied how the environments of studying craft with fabrics in elementary school, especially the differences of teacher types in charge, influenced the basic knowledge, skills and awareness of the students on craft. 


\section{Background \\ Learning craft with fabrics in home economics}

In Japan, the goals and the contents of school education subjects are decided by The Course of Study of the Ministry of Education, Culture, Sports, Science and Technology (MEXT). The Course of Study have been revised approximately every ten years. The latest revision for elementary and junior high school took place in 2017. According to the Course of Study, craft with fabrics is named "Craft with fabrics to enrich our daily lives". It is one of the contents for healthy, comfortable, safe, and rich life with food, clothing, and housing. Its purposes for elementary school students are as follows (MEXT, 2017).

- Students can acquire the knowledge and skills to understand the materials or procedures necessary for production.

- Students can acquire the knowledge and skills to make a production plan.

- $\quad$ Students can acquire the knowledge and skills to understand sewing methods and safe handling of tools according to purpose for hand sewing or machine sewing, and to do them properly.

- Students can make a production plan of things using fabric to enrich their daily lives.

- Students can devise for production of things using fabric.

In actual situation of craft education, many students favored craft learning with fabric, but they felt they were not good at it. About craft with fabric, $73.1 \%$ of boys, $85.7 \%$ of girls answered "I like studying craft with fabric" in the survey of Takeyoshi and Tatano (2005). However, $49.0 \%$ of boys and $33.1 \%$ of girls answered "I am rather good at" only. Watase (2010) pointed out that one of the reason for the diffidence was that they had no experience of craft with fabric except home economics classes. Ogino \& Iwaki (1977) point out that craft skills with fabric can be efficiently learned from 5th grade of elementary school to 3rd grade students of junior high school students. In addition, the skill was also retained even being college students (Inoue, 1983).

\section{Home economics Teachers in elementary schools}

At elementary schools in Japan, one class teacher is responsible for all subjects for class students (up to 40 students for 5 th and 6th graders) in general. Some subjects are exchanged in charge with another teacher or sometimes by teacher of the subject major. Regarding home economics teaching, the most common teacher is the classroom teacher, then the other class teachers or home economics teacher (Elementary and Secondary Education Bureau of MEXT, 2015).

We thought that each types of teachers in charge for teaching home economics have some advantages and some disadvantages. Classroom teachers know well about the students' abilities and living conditions, but many of the teachers have little substantial experience of teaching home economics (Yamamoto \& Ito, 2016, Takagi, 2015). Teachers in the home economics majors have a high level of knowledge and skills. However, they do not know much about the students and the students' daily lives as they get together with the students only in home economics class. 


\section{Literature Review \\ Teaching of craft with fabrics}

According to the survey of university students in the teacher education course by Morita (2015), the correct answer rate of craft education was lower than food and nutrition. Kobayashi and Yanagi $(2007,2008)$ pointed out that most of the skills of craft with fabrics were learned in school education, the actual skill (back stitch, sewing machines uses, ball knots, end knots, etc.) of university students was considerably low in contrast with their high self-evaluation. Kashiwazaki, Maeda \& Hikage (2008), and Maeda, Kashiwazaki \& Hikage (2009) also pointed out that university students of teacher education courses had clearly lower craft skills than cooking skills from the survey of students of elementary school, junior high school, and university. Morita (2015) also pointed out the correct answer rates of the craft were the lowest by the survey of university students in the teacher education course.

The skills acquired at elementary school tended to decline after junior high school. Miwa et al. (2001) revealed that the skill differences at the early stages of craft at the elementary school had great influences on the proficiency of the subsequent skills. Takamori (1985) also surveyed the students of the teacher education course and inferred that the difference in study experiences of home economics at elementary schools had some serious impacts on students' view of home economics.

\section{Education of craft with fabrics in elementary school}

Elementary school teachers recognize the importance of craft education. Home economics teachers strongly grasped the two points of educational significance of craft education; acquisition of living skills and accomplishment feeling and satisfaction by production (Tatano \& Takeyoshi, 2006). Teachers who instructed the craft with fabrics thought that the students worked more diligently than other teaching materials (Tatano \& Takeyoshi, 2006, Ikezaki, 2006). The students also perceived the craft activities as meaningful activities (Takeyoshi \& Tatano, 2005). Okawa et al. (1976) analyzed the students' impressions and pointed out the pleasure of learning, the sense of accomplishment, and the desire for further learning. Kaji (2011) also described that the students realized feeling of satisfaction, joy, excitement, refined sensitivity, and were able to learn the power to live by themselves.

In the 1998 survey of university students, $91.3 \%$ of females and $65.9 \%$ of males were interested in craft with fabrics. However, they were dissatisfied with "I do not have enough time" or "I could not ask to the teacher as soon as I wanted" (Miwa et al., 2001). Skills acquired at elementary school tended to decline after junior high school (Kashiwazaki, Maeda \& Hikage, 2008, Maeda et al., 2009). Hayami and Kuromitsu (2014) also pointed out the necessity of repeat learning to acquire the reliable skills.

Early learning of craft in home economics at elementary school is very important. It has been clarified that the difference in their experience had a great influence on the degree of proficiency of the subsequent skills (Miwa et al., 2001) and the view on subjects to home economics. (Takamori, 1985) 
It was indicated that one of the reasons for teachers' difficulty in teaching craft was in teaching materials (Kawai et al, 2008). In the 1980's, teaching materials of the craft education were designated the things to be produced, such as "cover of the pillow". Since around 1990, only the objectives such as "Let's make it with cloth." or "Let's make things to make life fun" were shown (Takagi, 2012). The students should decide what to make themselves. As a result, some problems occurred such as the skills to be acquired were not clearly recognized, only completion was the purpose, the burden of teachers increased markedly (Sasaki \& Saikai, 2017, Ogawa \& Maeda, 2012). In order to improve these situations, some researches to propose new teaching materials and teaching method for craft education have also been reported, for example, mask making (Nakazawa et al., 2011), finger knitting (Suzuki et al., 2007), machine sewing materials (Matsui et al., 1992, Goto et al., 1992), use of table for production plan (Kobayashi \& Kotani, 2010), teaching materials considering the continuity of learning in elementary and middle school (Kawai et al., 2008) and a proposal to reorganize clothing education with focusing on craft (Takeyoshi \& Tatano, 2005, Tatano \& Takeyoshi, 2006).

\section{New value of craft education}

In recent years, new values and meanings have been reported about craft education, such as the means of learning problem solving (Pöllänen, 2009), the significance as a mean of self-expression (Pöllänen, 2009), the significance of fostering communication skills (Okada \& Kawahara, 2009), the collaboration with science, technology, engineering, and math education (Shirley \& Kohler, 2012), the collaboration with technology education (Zuga, 1996, Volane, 2014, Mawson, 2013, Jarvinen \& Rasinen, 2015), the significance of collaboration with Social study (Bennett, 2008), the collaboration with design education (Ahlberg, Aanismaa \& Dillon, 2005), the effectd of suppression of violent behavior in teens (Crane, 2010), and the prevention of aging (Parisi et al., 2012). Making things, especially craft education with fabrics of soft and good touch is value reviewed.

From these studies, the craft education in home economics at the elementary school is significant and have a serious impact on subsequent impression, knowledge and skills for the students. If there are some differences of knowledge, impression, knowledge and skills acquired in elementary school, they will have influences on subsequent skills, knowledge and impressions. Improvement of craft education of home economics in elementary school is one of urgent issues.

\section{Objectives}

This research is aimed to study the influences of different types and numbers of the teachers of craft education in elementary school on impression, knowledge and skills for the craft of the students by the survey of the junior high school students immediately after entering junior high school. From the actual situation of the types of the teachers, we thought that the classroom teachers know well about the students' abilities and living conditions as they spend much time with the classroom students. But many of the classroom teachers have little 
substantial experiences of teaching home economics (Ito \& Yamamoto, 2016, Takagi, 2015). The teachers in the home economics majors have high level of knowledge and skills. However, they do not know much about the students or students' daily lives since they spend time together in home economics classes only. Additionally, the lessons by two teachers might be more capable of responding to the students than one teacher's lessons.

Therefore, we surveyed the students who studied craft at elementary school with a classroom teacher, a home economics major teacher, and two teachers (a classroom teacher and an assistant teacher). From the results of this research, we would like to consider what are the influences on craft education, and make some suggestions for teacher education curriculum to improve.

\section{Methodology}

A questionnaire survey was conducted for first-year 219 students (91 male, 128 females) immediately after enrolling in junior high school in Takamatsu city in Japan in April 2011. The contents of the questionnaire were impression, skills, and knowledge of the craft with fabrics in elementary school. In the survey and analysis, we adhered to the code of ethics in dealing with respondents. Only statistical processing was done in order not to identify individuals considering privacy.

Of all the questionnaires, we analyzed those from four elementary schools in the school district. The teachers who were in charge of home economics at these four elementary schools were one classroom teacher at two schools (abbreviated as $\mathrm{CR}$ ), one classroom teacher and one assistant teacher at one school (abb. as CR\&TA), and one home economics major teacher at one school (abb. as HE). Table 1 shows the number of the students of those who were the subject of the analysis. There is no significant difference in the ratio of male and female students for each type of the teacher.

Even though six years have passed since the survey was carried out, the data of this survey will be very valuable for the students and teacher education programs, as there are few such surveys.

Table 1: Respondents' gender and their home economics teachers at elementary school

\begin{tabular}{|c|c|c|c|c|c|c|c|c|}
\hline & \multicolumn{2}{|c|}{ CR } & \multicolumn{2}{|c|}{ CR\&TA } & \multicolumn{2}{|c|}{$\mathrm{HE}$} & \multicolumn{2}{|c|}{ Total } \\
\hline & $\mathrm{n}$ & $\%$ & $\mathrm{n}$ & $\%$ & $\mathrm{n}$ & $\%$ & $\mathrm{n}$ & $\%$ \\
\hline Male & 16 & 44.4 & 50 & 42.7 & 19 & 36.5 & 85 & 41.5 \\
\hline Female & 20 & 55.6 & 67 & 57.3 & 33 & 63.5 & 120 & 58.5 \\
\hline Total & 36 & 100.0 & 117 & 100.0 & 52 & 100.0 & 205 & 100.0 \\
\hline
\end{tabular}

\section{Results and Discussion \\ Students' impression}

Table 2 shows the students' impression of the craft with fabric. The numbers and percentages of students who answered "agree," "a little agree," "a little disagree," and "disagree" are listed. For both questions, about half of the students had positive answers, and half had negative answers as a whole. More students of 
HE had negative impression than CR and CR\&TA. But it had no significant difference from other groups.

\section{Study situation of craft with fabrics at elementary school}

Table 3 shows the answers of the students to the question of "Did you finish the craft work?" or "Did you use the items you made?". As a whole, about 30\% students did not finished the craft, and about $35 \%$ of the students did not use the items they made. This seems to be one of the causes of negative feelings for production learning.

By the types of teachers in charge, more students answered "finished" in the order of CR, HE, CR\&TA. And more answered "used" was HE, CR\&TA, and CR. In CR\&TA and HE group, the percentage of "finished" and "used" were almost equal, while the difference of the percentage of "finished" and "used" in CR group is $16.7 \%$.

Table 2: Students' impression of the craft with fabric

\begin{tabular}{|c|c|c|c|c|c|c|c|c|}
\hline & \multicolumn{2}{|c|}{$\mathrm{CR}$} & \multicolumn{2}{|c|}{ CR\&TA } & \multicolumn{2}{|c|}{$\mathrm{HE}$} & \multicolumn{2}{|c|}{ Total } \\
\hline & $\mathrm{n}$ & $\%$ & $\mathrm{n}$ & $\%$ & $\mathrm{n}$ & $\%$ & n & $\%$ \\
\hline \multicolumn{9}{|c|}{ Do you like craft with fabric? } \\
\hline Agree & 5 & 13.9 & 26 & 22.2 & 9 & 17.3 & 40 & 19.5 \\
\hline A little agree & 16 & 44.4 & 51 & 43.6 & 18 & 34.6 & 85 & 41.5 \\
\hline A little disagree & 10 & 27.8 & 22 & 18.8 & 17 & 32.7 & 49 & 23.9 \\
\hline Disagree & 5 & 13.9 & 18 & 15.4 & 8 & 15.4 & 31 & 15.1 \\
\hline Total & 36 & 100.0 & 117 & 100 & 52 & 100.0 & 205 & 100.0 \\
\hline \multicolumn{9}{|c|}{ Are you good at craft with fabric? } \\
\hline Agree & 3 & 8.3 & 12 & 10.3 & 2 & 3.8 & 17 & 8.3 \\
\hline A little agree & 15 & 41.7 & 49 & 41.9 & 17 & 32.7 & 81 & 39.5 \\
\hline A little disagree & 11 & 30.6 & 35 & 29.9 & 22 & 42.3 & 68 & 33.2 \\
\hline Disagree & 7 & 19.4 & 21 & 17.9 & 11 & 21.2 & 39 & 19.0 \\
\hline Total & 36 & 100.0 & 117 & 100 & 52 & 100.0 & 205 & 100.0 \\
\hline
\end{tabular}

Table 3: Students' answers to the questions "Did you finish the craft work?" and "Did you use the items you made?" in craft with fabrics in elementary school.

\begin{tabular}{|c|c|c|c|c|c|c|c|c|}
\hline & \multicolumn{2}{|c|}{ CR } & \multicolumn{2}{|c|}{ CR\&TA } & \multicolumn{2}{|c|}{$\mathrm{HE}$} & \multicolumn{2}{|c|}{ Total } \\
\hline & $\mathrm{n}$ & $\%$ & $\mathrm{n}$ & $\%$ & $\mathrm{n}$ & $\%$ & $\mathrm{n}$ & $\%$ \\
\hline \multicolumn{9}{|c|}{$\begin{array}{l}\text { Did you finish the craft } \\
\text { work? }\end{array}$} \\
\hline Yes & 29 & 80.6 & 75 & 64.1 & 40 & 76.9 & 144 & 70.2 \\
\hline No & 7 & 19.4 & 41 & 35.0 & 12 & 23.1 & 60 & 29.3 \\
\hline NA & 0 & 0.0 & 1 & 0.9 & 0 & 0.0 & 1 & 0.5 \\
\hline Total & 36 & 100.0 & 117 & 100.0 & 52 & 100.0 & 205 & 100.0 \\
\hline \multicolumn{9}{|c|}{ Did you use the items you made? } \\
\hline Yes & 23 & 63.9 & 78 & 66.7 & 39 & 75.0 & 140 & 68.3 \\
\hline No & 13 & 36.1 & 38 & 32.5 & 12 & 23.1 & 63 & 30.7 \\
\hline NA & 0 & 0.0 & 1 & 0.9 & 1 & 1.9 & 2 & 1.0 \\
\hline Total & 36 & 100.0 & 117 & 100.0 & 52 & 100.0 & 205 & 100.0 \\
\hline
\end{tabular}


Table 4 shows the results of the typical presentation methods of crafting process with fabrics by the teachers. In all cases, most of the responses answered that they looked the process that the teacher did. No significant differences were observed for the teachers in charge.

Table 5 shows the result of asking whether the method of craft with fabrics was easy to understand or was hard to understanding. About $65 \%$ of the 3 groups answered that it was easy to understand, but about 30\% was difficult to understand. There were not significant differences among 3 groups.

Table 6 shows the results of what students did when the methods were unknown. The most common answer was "I asked my friends," then "I asked the teacher." The percentage of "I asked the teacher" was highest in the CR group, followed by the HE and CR \& TA. The CR \& TA group was expected to have many opportunities to ask to the teacher, but the result was different.

Table 4: The most typical presentation method of crafting process with fabrics by the teachers

\begin{tabular}{|c|c|c|c|c|c|c|c|c|}
\hline & \multicolumn{2}{|c|}{ CR } & \multicolumn{2}{|c|}{ CR\&TA } & \multicolumn{2}{|c|}{ HE } & \multicolumn{2}{|c|}{ Total } \\
\hline & $\mathrm{n}$ & $\%$ & $\mathrm{n}$ & $\%$ & $\mathrm{n}$ & $\%$ & $\mathrm{n}$ & $\%$ \\
\hline $\begin{array}{l}\text { looking at the steps } \\
\text { by the teacher }\end{array}$ & 29 & 80.6 & 98 & 83.8 & 44 & 84.6 & 171 & 83.4 \\
\hline $\begin{array}{l}\text { handout showing the } \\
\text { steps }\end{array}$ & 3 & 8.3 & 3 & 2.6 & 1 & 1.9 & 7 & 3.4 \\
\hline $\begin{array}{l}\text { sample made by the } \\
\text { teacher }\end{array}$ & 2 & 5.6 & 11 & 9.4 & 7 & 13.5 & 20 & 9.8 \\
\hline Others & 2 & 5.6 & 4 & 3.4 & 0 & 0.0 & 6 & 2.9 \\
\hline NA & 0 & 0.0 & 1 & 0.9 & 0 & 0.0 & 1 & 0.5 \\
\hline & 36 & 100.0 & 117 & 100.0 & 52 & 100.0 & 205 & 100.0 \\
\hline
\end{tabular}

Table5: Students' impression of understanding of the crafting process with fabrics

\begin{tabular}{|c|c|c|c|c|c|c|c|c|}
\hline & \multicolumn{2}{|c|}{$C R$} & \multicolumn{2}{|c|}{ CR \& TA } & \multicolumn{2}{|c|}{$\mathrm{HE}$} & \multicolumn{2}{|c|}{ Total } \\
\hline & $\mathrm{n}$ & $\%$ & $\mathrm{n}$ & $\%$ & $\mathrm{n}$ & $\%$ & $\mathrm{n}$ & $\%$ \\
\hline Easy to understand & 24 & 66.7 & 78 & 66.7 & 35 & 67.3 & 137 & 66.8 \\
\hline Hard to understand & 12 & 33.3 & 38 & 32.5 & 16 & 30.8 & 66 & 32.2 \\
\hline NA & 0 & 0.0 & 1 & 0.9 & 1 & 1.9 & 2 & 1.0 \\
\hline Total & 36 & 100.0 & 117 & 100.0 & 52 & 100.0 & 205 & 100.0 \\
\hline
\end{tabular}

Table 6: The most typical behavior of the students when the methods were unknown

\begin{tabular}{|c|c|c|c|c|c|c|c|c|}
\hline & \multicolumn{2}{|c|}{$\mathrm{CR}$} & \multicolumn{2}{|c|}{ CR\&TA } & \multicolumn{2}{|c|}{$\mathrm{HE}$} & \multicolumn{2}{|c|}{ Total } \\
\hline & $\mathrm{n}$ & $\%$ & $\mathrm{n}$ & $\%$ & $\mathrm{n}$ & $\%$ & $\mathrm{n}$ & $\%$ \\
\hline I asked the teacher. & 15 & 41.7 & 29 & 24.8 & 19 & 36.5 & 81 & 39.5 \\
\hline I asked my friend. & 16 & 44.4 & 72 & 61.5 & 28 & 53.8 & 116 & 56.6 \\
\hline I asked my family. & 0 & 0.0 & 2 & 1.7 & 0 & 0.0 & 2 & 1.0 \\
\hline I examined by myself. & 3 & 8.3 & 9 & 7.7 & 3 & 5.8 & 15 & 7.3 \\
\hline I did suitably. & 2 & 5.6 & 2 & 1.7 & 1 & 1.9 & 5 & 2.9 \\
\hline I gave up. & 0 & 0.0 & 2 & 1.7 & 1 & 1.9 & 3 & 1.5 \\
\hline NA & 0 & 0.0 & 1 & 0.9 & 0 & 0.0 & 1 & 0.5 \\
\hline
\end{tabular}




\section{Student's knowledge of craft with fabrics}

Table 7 shows the numbers and percentages of the student who answered correctly the name of the craft tools. In three groups, the correct rates were high with iron, thread trimmer, tailor's choke and needle, but low with hand sewing thread, sewing needle and sewing thread. CR\&TA group had high rates of correct answers. Significant differences were found in sewing needle, machine sewing threads, tailor's chalk, pincushion, scissors. CR \& TA group was significantly higher than other two groups.

\section{Student's skills of craft with fabrics}

Table 8 shows the percentage of students who responded that they acquired the basic skills of craft with fabrics, namely threading needle, knot, end knot, and ball binding and button sewing. The numbers and percentages of the students who acquired the most basic skills were listed. Significant differences were observed among three groups for the knot, end knot. The results of CR and CR\&TA were higher than HE. In this survey, the teacher's skill was not related to students' skills. It is worth noting that those who answered that they were not acquired were about $35 \%$ in threading needle, about $15 \%$ in end knot, about 40 $50 \%$ in button sewing for all groups.

Table 7: The student who answered correctly the name of the craft tools

\begin{tabular}{|c|c|c|c|c|c|c|c|}
\hline & \multicolumn{2}{|r|}{$\mathrm{CR}$} & \multicolumn{2}{|c|}{ CR \& TA } & \multicolumn{2}{|c|}{$\mathrm{HE}$} & \multirow[t]{2}{*}{ Chi-test } \\
\hline & $\mathrm{n}$ & $\%$ & $\mathrm{n}$ & $\%$ & $\mathrm{n}$ & $\%$ & \\
\hline Sewing needle & 10 & 27.8 & 53 & 45.3 & 14 & 26.9 & * \\
\hline Pin & 26 & 72.2 & 101 & 86.3 & 42 & 80.8 & - \\
\hline Hand sewing thread & 6 & 16.7 & 26 & 22.2 & 5 & 9.6 & - \\
\hline $\begin{array}{l}\text { Machine sewing } \\
\text { thread }\end{array}$ & 9 & 25.0 & 56 & 47.9 & 10 & 19.2 & $* * *$ \\
\hline Tailor's chalk & 28 & 77.8 & 102 & 87.2 & 34 & 65.4 & $* * *$ \\
\hline Pincushion & 12 & 33.3 & 98 & 83.8 & 29 & 55.8 & $* * *$ \\
\hline Clippers & 32 & 88.9 & 107 & 91.5 & 45 & 86.5 & - \\
\hline Scissors & 13 & 36.1 & 74 & 63.2 & 25 & 48.1 & ** \\
\hline Iron & 34 & 94.4 & 115 & 98.3 & 48 & 92.3 & - \\
\hline
\end{tabular}

${ }^{*} \mathrm{p}<0.05,{ }^{* *} 0.05>\mathrm{p}>0.005,{ }^{* * *} \mathrm{p}<0.005$

Table 8:. Percentage of students who responded that they acquired the basic skills of craft with fabrics

\begin{tabular}{|c|c|c|c|c|c|c|c|}
\hline & \multicolumn{2}{|c|}{ CR } & \multicolumn{2}{|c|}{ CR \& TA } & \multicolumn{2}{|c|}{$\mathrm{HE}$} & \multirow{2}{*}{$\begin{array}{c}\text { Chi-test } \\
\text { among } 3 \text { groups }\end{array}$} \\
\hline & $\mathrm{n}$ & $\%$ & $\mathrm{n}$ & $\%$ & $\mathrm{n}$ & $\%$ & \\
\hline $\begin{array}{l}\text { Threading } \\
\text { needle }\end{array}$ & 24 & 66.7 & 80 & 68.4 & 35 & 67.3 & - \\
\hline Knot & 34 & 94.4 & 111 & 94.9 & 41 & 78.8 & $* * *$ \\
\hline End knot & 29 & 80.6 & 103 & 88.0 & 35 & 67.3 & ** \\
\hline Button sewing & 20 & 55.6 & 72 & 61.5 & 30 & 57.7 & - \\
\hline
\end{tabular}


From these results, there was no significant difference among CR, CR\&TA, and HE in the students' impression of craft education at the primary school. The percentages of respondents who answered they got the skills were significantly higher in CR \& TA. Regarding knowledge, CR and CR \& AT were significantly higher than HE. The teacher's knowledge and skills were supposed to be higher in $\mathrm{HE}$ than in CR and AT, but the responses of students' knowledge and skills did not match these. It was presumed that the relationship between teachers and students affected these results rather than the teacher's knowledge and skills.

This might be the results of education for elementary school students. CR teachers spent much more time with the CR students. Therefore, they understood their CR students much more than HE teacher did. It is presumed that the relationships between the teacher and the students are more closely related to the students' knowledge and skills than to the teachers' knowledge and skills.

On the other hand, the problems that the overall retention rates of some knowledge and skills of the students were low. As this, most basic knowledge and skills will be a foundation for future learning, they will become bigger problems in junior high school. Improving knowledge and skills of CR teachers will be an indispensable task in teacher education of university.

\section{Conclusion}

In this research, the survey of craft learning in elementary school for junior high school students immediately after enrollment was analyzed with the types of the teacher in charge of home economics class. As a result, there were not significant differences of impression and experience of the craft classes. However, there were significant differences in the knowledge of the craft tools and some skills. Higher results were obtained by the students studied with classroom teachers than a home economics major teacher. From these results, it was presumed that the deep daily relationship between students and teachers was highly effective in craft education for elementary school students.

Especially about half of the students with negative emotions such as dislike, weakness, and about 30\% students answered that they felt difficulty to understand the crafting process. About $40 \%$ of respondents answered that they could not do the most basic manufacturing techniques such as threading and button sewing. The results of craft education as a whole were not so high. It is urgent and essential to solving this problem.

Mitsuno \& Oguchi (2009) pointed out that demonstrations by teachers were effective for understanding the crafting process for elementary school students. Utilizing IT equipment will help the students to acquire the knowledge and skills as they can look the demonstrations repeatedly with talking with their classmates. In teacher education in university for elementary school teachers, it is desirable to acquire skill knowledge perfectly and to demonstrate it clearly with using IT. 


\section{Limitations}

This survey was conducted at one junior high school and is a small-scale survey. The influence of the community, the school, and the individual teacher also might be great. Also, because students' knowledge and skills were also impression of students, even if students answered they could do, it did not mean what they were actually able to. However, recognizing the positive and negative effects of the type of the teacher will make it possible to suggest for teacher education to lead to better craft education.

\section{References}

Agrawal, T. (2013). Vocational education and training programs (VET): An Asian perspective. Asia-Pacific Journal of Cooperative Education, 14(1), 15-26.

Ahlberg, M., Aanismaa, P. \& Dillon, P. (2005). Education for Sustainable Living: Integrating theory, practice, design, and development. Scandinavian Journal of Educational Research, 49(2), 167-186.

Bennett, L. (2008). Elementary Students Quilting through Social Studies. The Journal of Aesthetic Education, 42, 90-99.

Crane, C. E. (2010). An After School Program to Reduce Teen Violence, Recidivism, and Prepare Teens for the Workplace in Douglas County, Georgia. Public Health Theses. Paper 144.

Elementary and Secondary Education Bureau of Ministry of Education, Culture, Sports, Science and Technology (MEXT), (2015). Current state of school and faculty staff. http://www.mext.go.jp/b_menu/shingi/chukyo/chukyo3/052/siryo/ icsFiles/afieldfile/2015/02/18/1355024_4.pdf

Fujiwara, A. (1987). Present situations and problems of Homemaking education in the elementary schools in Okinawa. (2) -Teachers' evaluation of the contents of Homemaking education-. Bulletin of College of Education, University of the Ryukyus, Part 2, 30, 281-292.

Fujiwara, A., \& Toumon, S. (1987). Present situations and problems of Homemaking education in the elementary schools in Okinawa. (1) -Various types of teachers teaching Homemaking and their view of the subject-. Bulletin of College of Education, University of the Ryukyus, Part 2, 30, 271-279.

Goto, M., Osaki, H. \& Nishimura, Y. (1992). A Case Study on Effective instruction for Elementary Sewing Classes (3) : Verification of Effectiveness of a Training Cloth. Journal of the Japan Association of Home Economics Education, 35(2), 21-25.

Hayami, T., \& Kuromitsu, T. (2014). The Issues of University Students' Acquisition of Knowledge and Skill in Cooking and Clothing Production in Home Economics. Journal of the Japan Association of Home Economics Education, 57(1), 14-21.

Inoue, T. (1983). The Study on the Development of living abilities related to homemaking education (2) -Occupational abilities-. Journal of Nakamura Gakuen University, 6, 149-157.

Ito, K. \& Yamamoto, N. (2016). A Survey of safe education in clothing Practice of elementary and junior high school. Abstracts of the Meeting \& Seminar Research Presentation of Japan Association of Home Economics Education, 59, 69. https://doi.org/10.11549/jhee.59.0_69

Jarvinen, E-M., \& Rasinen, A. (2015). Implementing technology education in Finnish general education schools: studying the cross-curricular theme 'Human being and technology.' International Journal of Technology Design Education, 25, 67-84. 
Kaji, Y. (2011). Significance and aim of home economics education for elementary school students. In Kaji, M. \& Otsuka, M. (Eds), Pedagogy of home economics for elementary school students (pp2-9). Kyoto, Japan: Minerva Shobo.

Kawai, M., Taniguchi, A., Hirashima, N., Nakashima, T., Hishida, M., Kawasaki, C., \& Suzuki, Y. (2008). Study on the Systematic Matter of Clothing Construction in Home Economics Education in Elementary School, Junior High School and High School. Bulletin of Educational Research and Development Center, 17, 191-199.

Kashiwazaki, M., Maeda, Y., \& Hikage, Y. (2008). Survey of Knowledge on Words about Dressmaking for Elementary School Children, Junior High School Students, and College Students. Bulletin of Faculty of Education of Hirosaki University, 101, 109-114.

Kawahara, F., \& Okada M. (2009). Fostering Communication Skills of Elementary School Students in Home Economics Education (1): A Lesson Plan. Journal of the Japan Association of Home Economics Education, 52, 3-10.

Kobayashi, K., \& Yanagi, M. (2007). What should be taught in Home Economics at elementary-school teacher training course (1): Implications from a questionnaire survey and quizzes conducted among university/junior college students. Bulletin of Kyushu Women's University. Humanities and Social Science, 44(1), 29-45.

Kobayashi, K., \& Yanagi, M. (2008). What should be taught in Home Economics at elementary-school teacher training course (2): Implications from the skill test of needlework survey conducted among university/junior college students. Bulletin of Kyushu Women's University. Humanities and Social Science, 44(3), 17-29.

Kobayashi, Y., \& Kotani, A. (2010). An examination of teaching methods for production learning at homemaking education in elementary school: a trial class using production planning notes. Journal of the Japan Association of Home Economics Education, 53(1), 40-46.

Linda Bennett, L. (2008). Elementary Students Quilting through Social Studies. The Journal of Aesthetic Education, 42, 90-99.

Maeda, Y., Kashiwazaki, M., \& Hikage, Y. (2009). Survey of Knowledge on Words about Cooking for Elementary School Children, Junior High School Students, and College Students. The differences between Knowledge on Words about Cooking and Dressmaking? Bulletin of Faculty of Education of Hirosaki University, 102, 97-103.

Matsui, M., \& Nishimura, Y. (1992). A Case Study on Effective Instruction for Elementary Sewing Classes (2): Development of Teaching Materials. Journal of the Japan Association of Home Economics Education, 35(1), 73-76.

Matsui, M., OhsakiH., \& Nishimura, Y. (1992). A Case Study on Effective Instruction for Elementary Sewing Classes (1): Factors Influencing Pupils' Skills. Journal of the Japan Association of Home Economics Education, 35(1), 67-72.

Mawson, W. B. (2013). Emergent technological literacy: what do children bring to school? International Journal of Technology Des Education, 23, 443-453.

Ministry of Education, Culture, Sports, Science and Technology (MEXT). (2017). The Course of Study. http://www.mext.go.jp/component/a_menu/education/ micro_detail/_icsFiles/afieldfile/2017/05/12/1384661_4_2.pdf

Mitsuno, T., \& Oguchi, H. (2009). Effects of instruction timing on the basic sewing skills and products: From the subjective evaluation of the fifth graders and objective evaluation. Journal of the Japan Association of Home Economics Education, 52(3), 174-183. 
Miwa, S., Tuji, Y., Fuma, K., \& Nishimura, K. (2001). Current State and Trends of Clothing Area in Home Economics Education -Realities and Considerations of Dressmaking-. Bulletin of Gifu Women's College, 30, 153-159.

Morita, K. (2015), Problems of Teacher Training from the Viewpoint of Home Economics at Elementary School. Studies of Teacher Training Department of Hijiyama University and Hijiyama Junior College, 1, 181-186.

Muto, Y., \& Nishimura, Y. (1987b). Present Conditions of Homemaking Education in Elementary Schools in Okayama Prefecture (4). Journal of the Japan Association of Home Economics Education. 30(2), 20-26.

Muto, Y., \& Nishimura, Y. (1987a). Present Conditions of Homemaking Education in Elementary Schools in Okayama Prefecture (3). Journal of the Japan Association of Home Economics Education. 30(2), 13-19.

Muto, Y., Nishimura, Y., Okura, Y., \& Ishihara, K. (1986b). Present Conditions of Homemaking Education in Elementary Schools in Okayama Prefecture (2). Journal of the Japan Association of Home Economics Education. 29(3), 8-14.

Muto, Y., Nishimura, Y., Okura, Y., \& Ishihara, K. (1986a). Present Conditions of Homemaking Education in Elementary Schools in Okayama Prefecture (1). Journal of the Japan Association of Home Economics Education. 29(3), 1-7.

Nakazawa, H., Takagi, S., \& Ogino, M. (2011). Development and practice of production learning in home economics at elementary school: Mask making focusing on learning style. Studies on teaching materials, 22, 137-144.

Nishimura, T., \& Watanabe M. (1978). System of Teachers in Charge of Homemaking in Elementary Schools (2): Actual State of the Teachers in Charge of Homemaking and Their Views on Homemaking Education. Journal of the Japan Association of Home Economics Education, 21(1), 55-58.

Ogawa, I., \& Maeda, A. (2012). Textiles and clothing education in home economics in Japan. Proceedings of 10th Annual Conference of Hawaii International Conference on Education, 10, 2449-2450.

Ogino, C., \& Iwaki K. (1977). Thread knotting and Japanese dress making. Journal of Nagoya Women's College, 23, 69-74.

Okada M. \& Kawahara, F. (2009). Fostering Communication Skills of Elementary School Students in Home Economics Education (2): Evaluation of the Lesson Plan. Journal of the Japan Association of Home Economics Education, 52, 111-118.

Okawa, N., Kato, N., Shikanai, T., Jin, S., Takihara, M., \& Tamura, S. (1976). An Investigation into Clothing Work at Elementary School. Journal of the Japan Association of Home Economics Education. 19, 70-75.

Parisi, J. M., Rebok, G. W., Xue, Q.-L. Fried, L. P., Seeman, T. E., Tanner, E. K., Gruenewald, T. L., Frick, K. D., \& Carlson, M. C. (2012). The Role of Education and Intellectual Activity on Cognition. Journal of Aging Research, 2012, 1-9.

Pöllänen, S. (2009). Contextualising Craft: Pedagogical Models for Craft Education. International Journal of Art \& Design Education, 28, 249-260.

Sakai, T., \& Ikezaki, K. (2006). Research on the hand sewing of home economics in the elementary school (2) -Actual situation of hand-sewing skill and consideration of teaching material-. Bulletin of Tokyo Gakugei University, Educational Sciences, $57,341-350$.

Sasaki, T., \& Saikai, S. (2017). Method and tasks to make use of practices about "Dressmaking" for "Making things by using fabrics". Abstract of the conference $\mathcal{E}$ Seminar of Japan Japan Association of Home Economics Education, 60, 64.

Shirley, L. M., \& Kohler, J. (2012). Clothing and textiles: Reinforcing STEM education through family and consumer sciences curriculum. Journal of Family and 
Consumer Sciences Education, 30(2), 45-56. http://www.natefacs.org LJFCSE/v30no2/v30no2Shirley.pdf

Suzuki, A., Nishi, A., Kinoshita, M., \& Kishi, T. (2007). The study of the action learning strategy of home economics used to the practice in the daily life: The lesson "knitting with school fingers" in home economics of the elementary school. The Annals of Educational Research of Attached Schools of Hiroshima University, 35, $465-473$.

Takagi, S. (2013). Change of Teaching Materials in Home Economics Textbooks in an Elementary School. Bulletin of the Faculty of Education. Humanities and social sciences of Niigata University of Niigata University, 5(2), 181-188.

Takagi, S. (2015). Analysis of learning and challenge which an elementary schoolteacher recognize. Bulletin of the Faculty of Education. Humanities and Social Sciences of Niigata University. 7, 325-333.

Takamori, H. (1985). Education Students' Learning Experiences of homemaking at Elementary School and Their Views on the Subject Mainly in the Field of Clothing. Journal of the Japan Association of Home Economics Education, 9(4), 16517.

Takeyoshi, A. \& Tatano, M. (2005). Actual Conditions of Learning to Sew in Elementary School of Home Economics. Educational Clinical Integrated Studies of Shimane University, 4, 131-141.

Tatano, M., \& Takeyoshi, A. (2006). A Study of Educational Significance of Learning to Sew by Home Economics Teachers. Memoirs of the Faculty of Education, Shimane University, 39, 19-24.

Tokida, Y., \&Komatsu, H. (1984). A Survey of the State of Home Economics Instruction by Home Room Teachers in Elementary Schools of the three Kinki District Prefectures (1): Distinguished by Gender and Level of Concern. Journal of the Japan Association of Home Economics Education. 27(2), 27-33.

Volāne, E. (2014). The acquisition of primary school pupils' life activity skills in the aspect of teaching content of home economics and technologies. Rural Environment. Education. Personality, 7, 162-171.

Watanabe M., \&Nishimura, T. (1978). System of Teacher Assignment to Homemaking in Elementary School (I): The State in Aichi Prefecture. Journal of the Japan Association of Home Economics Education, 21(1), 50-54.

Watase, N. (2010). Developing Sewing Skills of Elementary School Students in Home Economics Education: Focus on "Sewing Buttons" and "Backstitch". Studies on home economics education in Tohoku, 9,17-25.

Yamashita, A. \& Kawamura, M. (2016). What is a difficulty for teachers to teach Home Economics education? -Through a young teacher's home economics classes-. Journal of Integrated Center for Clinical and Educational Practice of Saitama University. 15, 31-37.

Zuga, K. F. (1996). Reclaiming the voices of female and elementary school educators in technology education. Journal of Industrial Teacher Education, 33(3), 23-43. 